\title{
Canada and transboundary fisheries management in changing oceans: taking stock, future scenarios
}

\author{
U. R. Sumaila $^{1,2}$ and David L. VanderZwaag ${ }^{3,4}$
}

ABSTRACT. This article is the Introduction to the Special Feature entitled: Canada and Transboundary Fisheries Management in Changing Oceans: Taking Stock, Future Scenarios. We summarize the research context of the four papers in the Special Feature.

Key Words: adaptation; Atlantic; Canada; fish; oceans; Pacific; stocks; transboundary

Climate change and its challenges to transboundary fisheries management has become a hot topic in both international climate change reporting and in the academic literature (Miller et al. 2013, Pinsky et al. 2018, 2020, Mendenhall et al. 2020). The Intergovernmental Panel on Climate Change (IPCC) Special Report on the Ocean and Cryosphere in a Changing Climate highlights the potential for increasing international conflicts in fisheries management due to projected intensification of shifts in abundance and distribution of fish in response to the effects of climate change (Bindoff et al. 2019). The high likelihood of new transboundary fish stocks occurring within national exclusive economic zones (EEZs) is noted along with the new fisheries allocation problems (Bindoff et al. 2019).

The academic literature has burgeoned with scholarly lights being cast on various aspects of changing oceans and transboundary fisheries management. Some articles have focused on the factors important for effectively responding to shifting species and ecosystems, such as clarity in the provision of scientific advice (Galland et al. 2018) and majority-based decision making within regional fisheries management organizations (RFMOs; Pentz and Klenk 2017). One study has evaluated 12 RFMOs and their capacities to respond to climate change fluctuations in light of 28 factors, including adoption of precautionary and ecosystem approaches (Pentz et al. 2018), while another study identified 17 factors influencing the performance of RFMOs more broadly (Haas et al. 2020). Specific transboundary fisheries conflicts relating to climate change have been described, for example, the difficulty in reaching agreement on allocations of North Atlantic mackerel (Scomber scombrus) that has shifted into Faroese, Icelandic, and Greenlandic waters (Østhagen et al. 2020) and obtaining agreement on the management of Norwegian spring spawning herring (Clupea harengus) that has migrated toward Iceland (Gullestad et al. 2020, Hannesson 2020).

Actual experiences in addressing climate change within selected transboundary fisheries management arrangements have also been documented. Reviews have covered the Commission on the Conservation of Antarctic Marine Living Resources (Wendebourg 2020), the Inter-American Tropical Tuna Commission (Pentz and Klenk 2020), the Nauru Agreement in Oceania (Aqorau et al. 2018), and a range of RFMOs (Rayfuse 2019, Haward 2020).
The papers in this Special Feature add to the substantial literature on transboundary fisheries adaptations in a changing ocean with two original twists. First, the contributions focus on how the transboundary fisheries management arrangements of a specific country, Canada, have fared in addressing shifting species and ecosystems. Second, case studies in bilateral fisheries management challenges are included that go beyond the large scholarly focus on regional fisheries governance.

Two of the four articles in this Special Feature are devoted to taking stock. The contribution by Engler (2020) takes stock of the international law and policy seascape governing transboundary fisheries in the face of climate change and emphasizes the central importance of adopting an ecosystem approach. She describes the tensions within international fisheries law between holistic, precautionary, and adaptive responses required under the ecosystem approach to fisheries management (EAFM) and the long-standing international legal principles and practices favoring fragmentation, stability, and the status quo. She highlights the key ways in which transboundary fisheries management arrangements may be made more "climate ready" by (i) including climate change in scientific work plans or strategies; (ii) ensuring the rules for new fishing opportunities are clear and precautionary; (iii) enhancing cooperation across jurisdictional boundaries; (iv) expanding marine protected areas as an adaptive measure; and (v) revisiting allocation agreements in light of the changing fish distributions.

The article by Koubrak and VanderZwaag (2020) assesses the seaworthiness of transboundary fisheries management organizations and arrangements off Canada's North Atlantic and Pacific coasts to weather the rough waters of climate change as it results in the poleward shift in fish biomass. For the North Atlantic, the preparedness of three RFMOs, the North Atlantic Salmon Conservation Organization (NASCO), the Northwest Atlantic Fisheries Organization (NAFO), and the International Commission for the Conservation of Atlantic Tunas (ICCAT), is assessed along with Canada-United States bilateral cooperative management of Georges Bank groundfish. For the Pacific, the climate adaptability of two RFMOs, the North Pacific Fisheries Commission (NPFC) and the Western and Central Pacific Fisheries Commission (WCPFC), is evaluated along with the practice of two bilateral fisheries management organizations, the 
International Pacific Halibut Commission (IPHC) and the Pacific Salmon Commission (PSC).

The other two articles in the Special Feature, namely, PalaciosAbrantes et al. (2020) and Sumaila et al. (2020), are devoted to future scenarios in ecological and bioeconomic models that focus on the effects of climate change on fish stocks, their distribution, and productivity. Palacios-Abrantes et al. (2020) hypothesizes that ocean warming will alter the sharing of fish stocks between Canada and the United States, and that such changes will intensify under a high carbon emission scenario. These in turn will affect the stock-share ratio, i.e., the proportion of the total catch of a fish stock taken by a given country, of the fish stocks that are being jointly managed by the two countries. The study simulated multiple Earth System models together with species distribution models under two climate change scenarios. The authors then proceeded to study the specific cases of the joint management of Pacific halibut (Hippoglossus stenolepis) stocks and Atlantic cod (Gadus morhua), haddock (Melanogrammus aeglefinus), and yellowtail flounder (Limanda ferruginea) stocks. The results suggest that even under a low emission scenario, the stock-share ratios will change by 2050 relative to their present values as fish follow their optimal environment. For example, in the case of Pacific halibut, the projected poleward movement brought about by climate change is expected to result in the average stock-share ratio increasing by up to $25 \%$ in some northern regions and decreasing by $10 \%$ in southern regions, relative to the present ratio. The result reported in this article suggests that maintaining emissions at lower levels through 2050 would potentially leave unchanged the stock-share ratio of three regulatory areas (3AC and 4D) and negatively change regulatory area 2A. On the other hand, failing to achieve such a target will decrease the stock-share ratio in the most productive regulatory areas (2AC and $3 \mathrm{AB})$. The article concludes by highlighting the challenges that transboundary fisheries management will face as species shift their current distribution under a changing climate.

The second article, Sumaila et al. (2020), applies the concept of "threat points" in game theory (Sumaila 1999) to explore how stable the current management arrangements are between Canada and the United States for three shared transboundary fish stocks with climate change intensifying and affecting the productivity and distribution of the three stocks studied (Atlantic cod, Pacific halibut, and yellowtail flounder). A threat point is defined in this article as the payoffs that Canada and the United States take home given the current management arrangement between the two countries. This is an application of John Nash's "threat point," defined as the minimum payoffs, which each player in a game theoretic model must receive for the solution to a cooperative game to be stable (Nash 1953). This is usually the payoffs to players in a noncooperative game equilibrium. The threat points were computed as the current discounted profits that Canada and the United States derive from these three shared stocks, respectively. Next, the authors developed an ensemble of climatemarine ecosystem-economic models (Sumaila et al. 2015, 2019) and used them to determine how climate change is likely to change current profits received by each country relative to the shifts in their threat points. The potential shift in species distribution is projected to result in increasing catch of some species in Canada's EEZ. The average share of profit to the two countries changes for both Atlantic cod and yellowtail flounder under high emissions, whereas in the case of halibut, the share or proportions of profits is very stable regardless of the climate change scenario. In the case of Atlantic cod, the relative threat point payoffs to Canada as climate change intensifies shows the country's share of profit increasing from a low of $39 \%$ initially to a high of $65 \%$ of total profit under high emissions. These relative changes in threat points are used as the basis for discussing the stability of the current transboundary management agreements between Canada and the United States for these important shared stocks.

Together, the four articles in this Special Feature shed light on four governance realities surrounding transboundary fisheries management in changing oceans. First, the imperative to consider climate change is not explicit in any treaty or founding documents, but arises indirectly through the responsibility to implement key international principles, such as precautionary and ecosystem approaches. Second, modeling science and projections are still rife with uncertainties that hamper their incorporation into decision making. Third, putting ecosystem-based fisheries management into transboundary practice remains politically difficult with managers continuing to rely on single stock assessments and to focus on the conservation of important commercial or recreational fish stocks. Losing or limiting catch quotas remains an overarching political and socioeconomic concern constraining the implementation of precautionary and ecosystem approaches. Fourth, the climate seaworthiness of transboundary fisheries management arrangements varies considerably. The article by Koubrak and VanderZwaag (2020) provides a qualified ranking into three categories, least, moderately, and most seaworthy, with NAFO standing out among the RFMOs as one of the most advanced in addressing shifting species and changing ecosystems. This is through its support for ecosystem productivity and multispecies modeling and its informal cooperation with the North-East Atlantic Fisheries Commission in managing a shared pelagic oceanic redfish stock linked to a climate-induced distribution shift.

The coeditors of this Special Feature wish to acknowledge various sources of research support. The articles were the product of a project, Canada and Transboundary Fisheries Management in Changing Oceans: Taking Stock, Future Scenarios, funded by the Social Sciences and Humanities Research Council of Canada (SSHRC) through the OceanCanada Partnership, a six-year research initiative (2014-2020 extended to 2022) based at the University of British Columbia, which is a partnership consisting of five other Canadian universities, nongovernmental organizations, and Fisheries and Oceans Canada. Editorial assistance was provided by Susan Rolston at Seawinds Consulting Services with financial support from the Schulich Academic Excellence Fund, Schulich School of Law, Dalhousie University. The Canada First Research Fund through the Ocean Frontier Institute (OFI) assisted research on Canada's regional and bilateral fisheries arrangements.

Responses to this article can be read online at: https://www.ecologyandsociety.org/issues/responses. php/12209 


\section{Acknowledgments:}

This Special Feature is a product of the Ocean Canada Partnership funded by the Social Sciences and Humanities Research Council of Canada.

\section{LITERATURE CITED}

Aqorau, T., J. Bell, and J. N. Kittinger. 2018. Good governance for migratory species. Science 361(6408):1208-1209. https://doi. org/10.1126/science.aav2051

Bindoff, N. L., W. W. L. Cheung, J. G. Kairo, J. Aristgui, V. A. Guinder, R. Hallbert, N. Hilmi, N. Jico, M. S. Karim, L. Levin, S. O'Donoghue, S. R. Purca Cuicapuse, B. Rinkevich, T. Suga, A. Tagliabue, and P. Williamson. 2019. Changing ocean, marine ecosystems, and dependent communities. Pages 447-587 in H. O. Pörtner, D. C. Roberts, V. Masson-Delmotte, P. Zhai, M. Tignor, E. Poloczanska, K. Mintenbeck, A. Alegria, M. Nicolai, A. Okem, J. Petzold, B. Rama, and N. M. Weyer, editors. IPCC special report on the ocean and cryosphere in a changing climate. In press.

Engler, C. 2020. Transboundary fisheries, climate change, and the ecosystem approach: taking stock of the international law and policy seascape. Ecology and Society 25(4):43. https://doi. org/10.5751/ES-11988-250443"

Galland, G. R., A. E. M. Nickson, R. Hopkins, and S. K. Miller. 2018. On the importance of clarity in scientific advice for fisheries management. Marine Policy 87:250-254. https://doi.org/10.1016/ j.marpol.2017.10.029

Gullestad, P., S. Sundby, and O. S. Kjesbu. 2020. Management of transboundary and straddling fish stocks in the Northeast Atlantic in view of climate-induced shifts in spatial distribution. Fish and Fisheries 21:1008-1026. https://doi.org/10.1111/ faf. 12485

Haas, B., J. McGee, A. Fleming, and M. Haward. 2020. Factors influencing the performance of regional fisheries management organizations. Marine Policy 113:103787. https://doi.org/10.1016/ j.marpol.2019.103787

Hannesson, R. 2020. The Nash-Cournot approach to shared fish stocks: an empirical investigation. Marine Policy 118:103978. https://doi.org/10.1016/j.marpol.2020.103978

Haward, M. 2020. Governing oceans in a time of change: fishing for the future? Edward Elgar, Cheltenham, UK.

Koubrak, O., and D. L. VanderZwaag. 2020. Are transboundary fisheries management arrangements in the Northwest Atlantic and North Pacific seaworthy in a changing ocean? Ecology and Society 25(4):42. https://doi.org/10.5751/ES-11835-250442

Mendenhall, E., C. Hendrix, E. Nyman, P. M. Roberts, J. Robison Hoopes, J. R. Watson, V. W. Y. Lam, and U. R. Sumaila. 2020. Climate change increases the risk of fisheries conflict. Marine Policy 117:103954. https://doi.org/10.1016/j.marpol.2020.103954

Miller, K. A., G. R. Munro, U. R. Sumaila, and W. W. L. Cheung. 2013. Governing marine fisheries in a changing climate: a game- theoretic perspective. Canadian Journal of Agricultural Economics/Revue canadienne d'agroeconomie 61(2):309-334. https://doi.org/10.1111/cjag.12011

Nash, J. 1953. Two-person cooperative games. Econometrica 21:128-140. https://doi.org/10.2307/1906951

Østhagen, A., J. Spijkers, and O. A. Totland. 2020. Collapse of cooperation? The North-Atlantic mackerel dispute and lessons for international cooperation on transboundary fish stocks. Maritime Studies 19:155-165. https://doi.org/10.1007/s40152-020-00172-4

Palacios-Abrantes, J., U. R. Sumaila, and W. W. L. Cheung. 2020. Challenges to transboundary fisheries management in North America under climate change. Ecology and Society 25(4):41. https://doi.org/10.5751/ES-11743-250441

Pentz, B., and N. Klenk. 2017. The 'responsiveness gap' in RFMOs: the critical role of decision-making polices in the fisheries management response to climate change. Ocean \& Coastal Management 145:44-51. https://doi.org/10.1016/j. ocecoaman.2017.05.007

Pentz, B., and N. Klenk. 2020. Understanding the limitations of current RFMO climate adaptation strategies: the case of the IATTC and Eastern Pacific Ocean. International Environmental Agreements 20:21-39. https://doi.org/10.1007/s10784-019-09452-9

Pentz, B., N. Klenk, S. Ogle, and J. A. D. Fisher. 2018. Can regional fisheries management organizations (RFMOs) manage resources effectively during climate change? Marine Policy 92:13-20. https://doi.org/10.1016/j.marpol.2018.01.011

Pinsky, M. L., E. Fenichel, M. Fogarty, S. Levin, B. McCay, K. St. Martin, R. L. Selden, and T. Young. 2020. Fish and fisheries in hot water: What is happening and how do we adapt? Population Ecology. https://doi.org/10.1002/1438-390x.12050

Pinsky, M. L., G. Reygondeau, R. Caddell, J. Palacios-Abrantes, J. Spijkers, and W. W. L. Cheung. 2018. Preparing ocean governance for species on the move. Science 360(6394):1189-1191. https://doi.org/10.1126/science.aat2360

Rayfuse, R. 2019. Addressing climate change impacts in regional fisheries management organizations. Pages 247-268 in R. Caddell and E. J. Molenaar, editors. Strengthening international fisheries law in an era of changing oceans. Hart, Oxford, UK. https://doi. org/10.5040/9781509923373.ch-011

Sumaila, U. R. 1999. A review of game-theoretic models of fishing. Marine Policy 23(1):1-10. https://doi.org/10.1016/ S0308-597X(97)00045-6

Sumaila, U. R., N. Hotte, A. Galli, V. W. Y. Lam, A. M. CisnerosMontemayor, and M. Wackernagel. 2015. Eco2: a simple index of economic-ecological deficits. Marine Ecology Progress Series 530:271-279. https://doi.org/10.3354/meps11278

Sumaila, U. R., J. Palacios-Abrantes, and W. W. L. Cheung. 2020. Climate change, shifting threat points, and the management of transboundary fish stocks. Ecology and Society 25(4):40. https:// doi.org/10.5751/ES-11660-250440

Sumaila, U. R., T. C. Tai, V. W. Y. Lam, W. W. L. Cheung, M. Bailey, A. M. Cisneros-Montemayor, O. L. Chen, and S. S. Gulati. 
2019. Benefits of the Paris Agreement to ocean life, economies, and people. Science Advances 5(2):eaau3855. https://doi. org/10.1126/sciadv.aau3855

Wendebourg, M. R. 2020. Southern Ocean fishery management - Is CCAMLR addressing the challenges posed by climate change? Marine Policy 118:103847. https://doi.org/10.1016/j.marpol.2020.103847 